\title{
Cost of Production for Processed Oranges Grown in Southwest Florida, 2015/16'
}

\author{
Ariel Singerman ${ }^{2}$
}

\section{Introduction}

This article presents the cost of production per acre for processed oranges in southwest Florida during 2015/16. The cost estimates below do not represent any individual operation. Instead, their purpose is to serve as a benchmark for the Florida citrus industry. Typical users of these estimates include growers, consultants, property appraisers, and researchers. By surveying growers regarding the costs of their caretaking programs, we ensured that the estimates reported in this article closely reflect growers' expenditures.

\section{Data}

A total of thirteen growers participated in the datacollection process by attending either of the two meetings at the UF/IFAS SWREC or Arcadia Extension office in May and June 2016, respectively. Growers brought a completed survey form to the meeting that had been distributed to them beforehand. The questionnaire asked growers to provide annual, per-acre costs by program for a "typical" irrigated, mature grove (10+ years old), including resets.

The data collection process was anonymous and confidential. During the meeting, each grower used a "clicker" or remote device to enter the costs for each caretaking program. The figures below were obtained by computing the weighted average of the responses by the acreage of each of the participating growers. The number of acres managed by their combined operations accounts for approximately

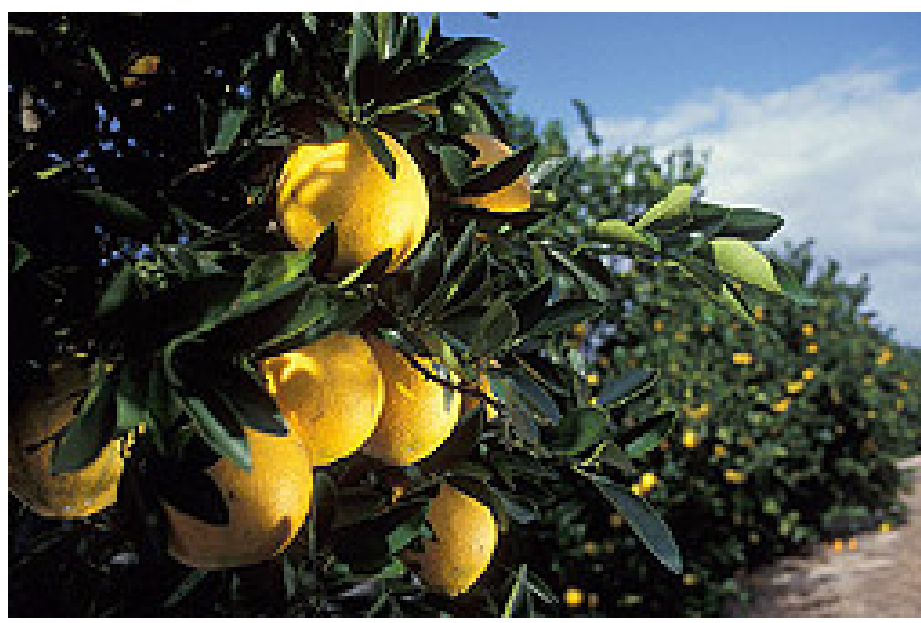

Credit: USDA

41,000 acres. The acreage for oranges in southwest Florida during 2015 was estimated at 257,298 (USDA-NASS 2015). Thus, the sample of growers represented $16 \%$ of the acreage devoted to oranges in that region.

Table 1 shows the costs of production by program. The estimates include both the cost of materials and the cost associated with their application. The total for weed management, which includes chemical and mechanical mowing as well as herbicides, was $\$ 210.09$ per acre. At $\$ 611.62$ per acre, foliar sprays were the largest expense in grove caretaking. Fertilizer was the second largest expense at $\$ 454.18$ per acre. Citrus Health Management Areas (CHMA) sprays accounted for $\$ 17.96$ per acre. The expense for pruning was

1. This is EDIS document FE1007, a publication of the Food and Resource Economics Department, UF/IFAS Extension. Published January 2017. Visit the EDIS website at http://edis.ifas.ufl.edu..

2. Ariel Singerman, assistant professor, Food and Resource Economics Department, UF/IFAS Extension, Citrus Research and Education Center, Lake Alfred, FL.

The Institute of Food and Agricultural Sciences (IFAS) is an Equal Opportunity Institution authorized to provide research, educational information and other services

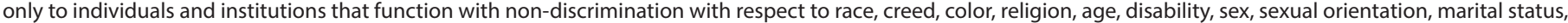

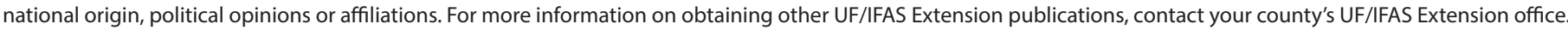
U.S. Department of Agriculture, UF/IFAS Extension Service, University of Florida, IFAS, Florida A \& M University Cooperative Extension Program, and Boards of County Commissioners Cooperating. Nick T. Place, dean for UF/IFAS Extension. 
$\$ 49.83$ per acre, while that for irrigation was $\$ 180.88$ per acre. Adding all the costs listed above, the cultural cost of growing oranges for processing during 2015/16 without tree replacement was $\$ 1,524.55$ per acre.

Growers were also asked to provide details regarding their reset practices, including the number of trees replaced in their groves. On average, growers replaced nine trees per acre during 2015/16. The total cost of tree replacement, including tree removal, site preparation, and care of young trees for those nine trees was estimated at $\$ 385.70$ per acre. Adding this cost yields a total production cost with tree replacement of $\$ 1,910.25$ per acre.

Figure 1 depicts a double pie chart. The larger pie shows the cost of each program as well as the percentage relative to the cultural production costs with tree replacement. The smaller pie in Figure 1 provides greater detail regarding the individual components included in the foliar spray category. The expense of $\$ 611.62$ was divided as follows: insecticides totaled $\$ 183.95$ per acre, (representing $10 \%$ of the cultural cost of production); fungicides accounted for $\$ 99.73$ per acre (5\%); foliar nutritionals for $\$ 165.91$ per acre (9\%); aerial application for $\$ 28.92$ per acre (1\%); and ground application of materials for $\$ 133.11$ per acre (7\%).

Figure 2 shows a comparison of the cost of the main production programs in $2015 / 16$ relative to $2014 / 15$. The

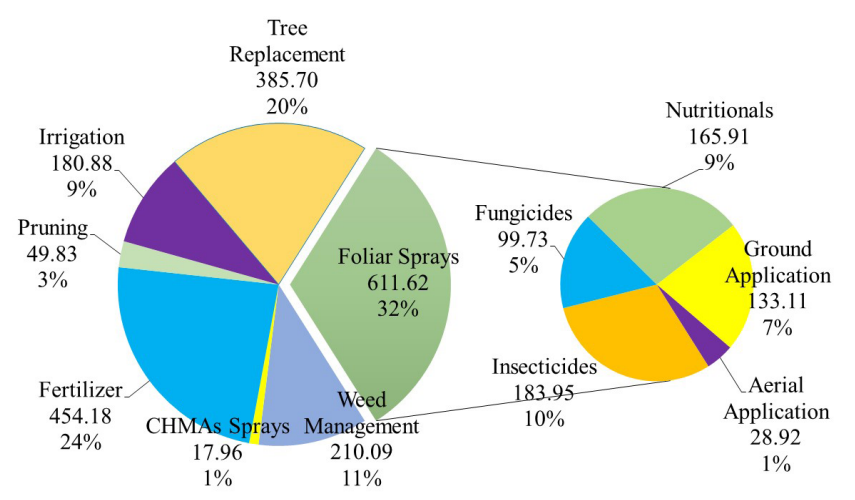

Figure 1. Cultural costs of production for processed oranges grown in southwest Florida, 2015/16

greatest change was the reduction in insecticide spending by $\$ 50$ per acre in 2015/16 compared to $2014 / 15$. Weed management and fertilizer expenses were reduced by $\$ 38$ and $\$ 33$ per acre while tree replacement expense increased by $\$ 39$ compared to $2014 / 15$.

In addition to cultural costs, growers typically incur other costs when managing their groves; these other costs include management, regulatory, and opportunity costs. Table 2

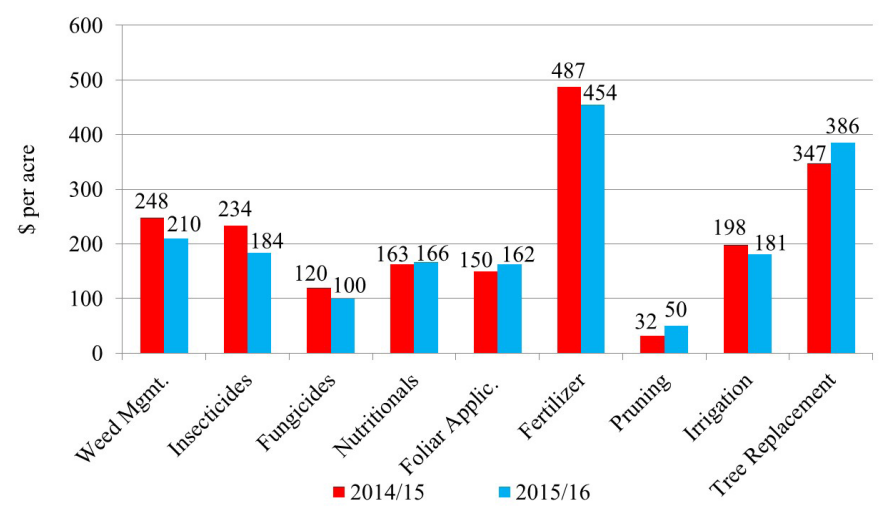

Figure 2. Cost of production by program for processed oranges grown in southwest Florida, 2014/15 vs. 2015/16

shows the total cost of production for processed oranges in southwest Florida during 2015/16 was $\$ 2,327.98$ per acre. Using this estimate, the breakeven prices per box for different levels of yield are presented in Table 3. Breakeven prices were calculated on an on-tree and delivered-in basis. The latter assumes harvesting costs per box were $\$ 3.22$, which is based on the results of the 2015/16 Picking, Roadsiding, and Hauling Charges for Florida Citrus survey (FE1005). The calculations in Table 3 also include the Florida Department of Citrus (FDOC) assessment of $\$ 0.23$ per box for the 2015/16 season. Thus, for example, the on-tree and delivered-in breakeven prices for covering the total costs of production with yields at 250 boxes per acre were $\$ 1.59$ and $\$ 2.18$ per pound solids.

\section{Summary}

This article presents a summary of the 2015/16 costs of production for processed oranges in southwest Florida. The methodology chosen to collect the data consisted of surveying growers directly to closely reflect growers' costs in the era of citrus greening (HLB). The total cost of production for processed oranges in 2015/16 was $\$ 2,327.98$ per acre, down $\$ 87.86$ per acre from last season.

\section{References}

United States Department of Agriculture, National Agricultural Statistics Service (USDA-NASS). 2015. Commercial Citrus Inventory: Preliminary Report. Florida Department of Agricultural Services. Maitland, FL. 
Table 1. Cultural costs of production per acre for processed oranges in southwest Florida, 2015/16

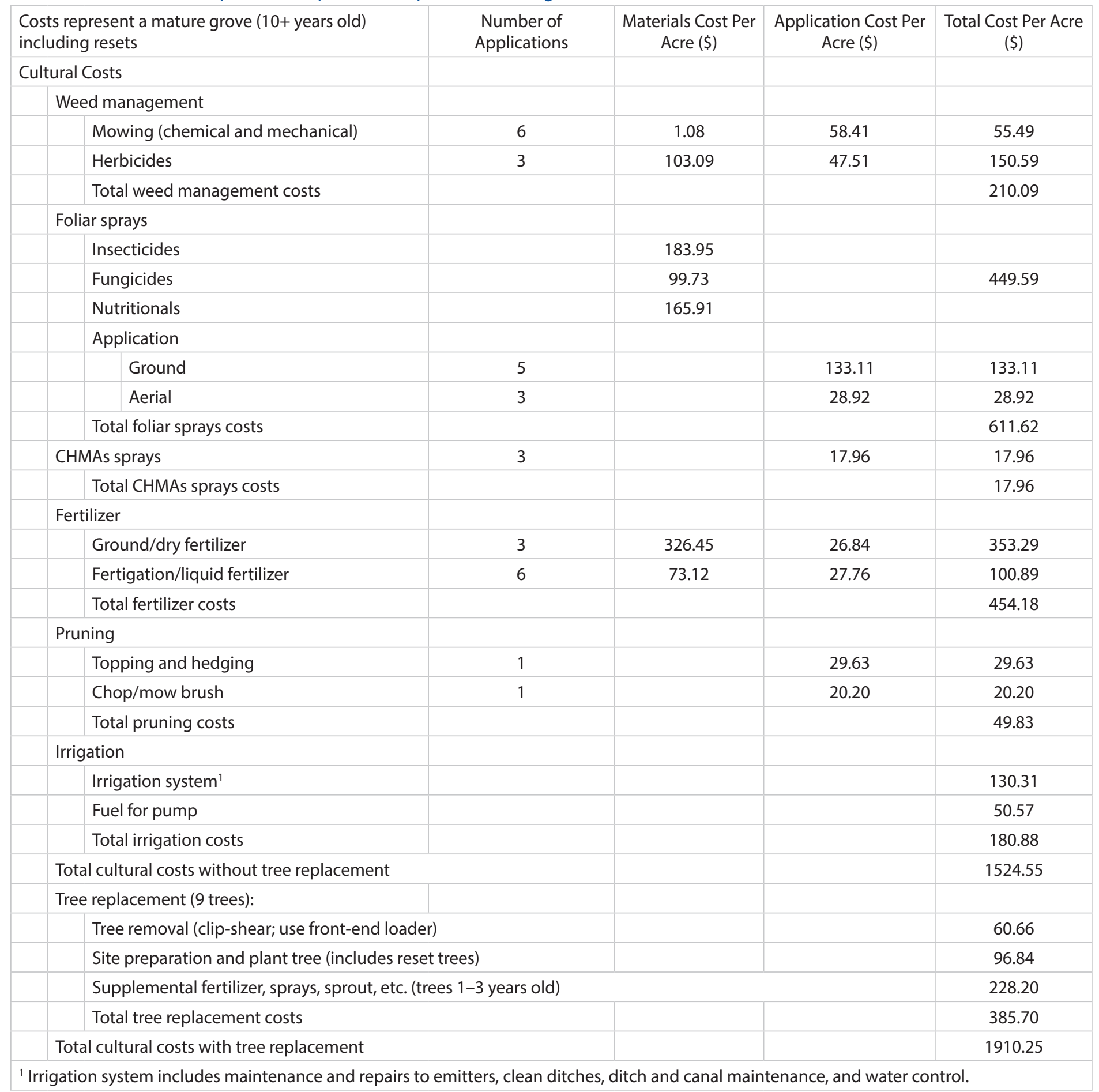


Table 2. Total costs of production per acre for processed oranges in southwest Florida, 2015/16

\begin{tabular}{|l|l|c|}
\hline \multicolumn{2}{|c|}{ Total Cultural Costs with Tree Replacement } & 1910.25 \\
\hline Other costs & 95.51 \\
\hline & Interest on operating (cultural) costs & 131.24 \\
\hline & Management cost & 28.73 \\
\hline & Property tax/water management assessment & 162.25 \\
\hline & Interest on average capital investment & 417.73 \\
\hline & Total other costs & 2327.98 \\
\hline Total costs
\end{tabular}

Table 3. Breakeven price per box for processed oranges in southwest Florida, 2015/16

\begin{tabular}{|c|c|c|c|c|c|c|c|c|c|}
\hline & \multicolumn{9}{|c|}{ Yield (boxes per acre) } \\
\hline & 175 & 200 & 225 & 250 & 275 & 300 & 325 & 350 & 375 \\
\hline & \multicolumn{9}{|c|}{ dollars per acre } \\
\hline $\begin{array}{l}\text { Cost of production per } \\
\text { acre }\end{array}$ & 2328 & 2328 & 2328 & 2328 & 2328 & 2328 & 2328 & 2328 & 2328 \\
\hline Pick and haul per acre & 564 & 644 & 725 & 805 & 886 & 966 & 1047 & 1127 & 1208 \\
\hline FDOC assessment & 40 & 46 & 52 & 58 & 63 & 69 & 75 & 81 & 86 \\
\hline $\begin{array}{l}\text { Total delivered-in cost } \\
\text { per acre }\end{array}$ & 2932 & 3018 & 3104 & 3190 & 3277 & 3363 & 3449 & 3535 & 3622 \\
\hline Breakeven price & \multicolumn{9}{|c|}{$\$$ per box } \\
\hline On-tree & 13.30 & 11.64 & 10.35 & 9.31 & 8.47 & 7.76 & 7.16 & 6.65 & 6.21 \\
\hline Delivered-in & 16.75 & 15.09 & 13.80 & 12.76 & 11.92 & 11.21 & 10.61 & 10.10 & 9.66 \\
\hline Breakeven price $^{1}$ & \multicolumn{9}{|c|}{ \$ per pound solids } \\
\hline On-tree & 2.27 & 1.99 & 1.77 & 1.59 & 1.44 & 1.32 & 1.22 & 1.14 & 1.06 \\
\hline Delivered-in & 2.86 & 2.58 & 2.35 & 2.18 & 2.03 & 1.91 & 1.81 & 1.72 & 1.65 \\
\hline
\end{tabular}

